УДК $338.242+664.76$

DOI: $10.15673 /$ fie.v11i2.1391

\author{
Нікішина О.В. \\ доктор економічних наук, старший науковий співробітник \\ завідувач відділом ринкових механізмів та структур \\ Інститут проблем ринку та економіко-екологічних досліджень НАН України \\ Французький бульвар, 29, м. Одеса, Україна, 65044 \\ E-mail: ksenkych@gmail.com \\ ORCID ID: 0000-0002-7172-3551
}

\title{
ЛОГІСТИЧНА СТРУКТУРА ТОВАРНОГО РИНКУ: ТЕОРЕТИЧНІ ПОЛОЖЕННЯ ТА ПРИКЛАДНІ АСПЕКТИ*
}

Стаття присвячена розробці теоретичних положень щодо формування логістичної структури товарного ринку та їх конкретизації шляхом емпіричних досліджень. Запропоновано авторське визначення категорії «логістичний ланцюг товарного ринку», обґрунтовано його відтворювальну природу й мету забезпечення розширеного відтворення ресурсів у ланках. У ході дослідження логістичної будови ринку доведено важливу роль зв'язків і взаємодій між суб'єктами ланок у фрормуванні структури ефективного логістичного ланцюга, виділено сім типів зв'язків з акцентом на зв'язки взаємодії. Обґрунтовано класифікацію логістичних ланцюгів товарних ринків, запропоновано нову класифікаційну ознаку - відтворювальна спроможність ринкових ланцюгів, яка дозволяє здійснити їх специфрікацію за обсягами створюваної доданої вартості. Вперше на основі відтворювального підходу встановлено закономірність багатофункціональної сутності логістичної операції, напрями зміни споживчої й доданої вартості у ринковому ланцюгу. На прикладі українського ринку зерна й продуктів його переробки визначено специфіку будови логістичного ланцюга, показано трансформаційний вплив сировинного експорту на структуру ринкового ланцюга, ідентифіковано його неефективні ланки. Наукова новизна проведеного дослідження полягає в розвитку теоретичних основ ринкової логістики, як нового напрямку логістики, що формує наукове підґрунтя для розробки державної логістичної політики в ринковому вимірі.

Ключові слова: логістичний ланцюг товарного ринку, структура, зв'язки, ланка, логістична операція, додана й споживча вартість, матеріальний потік, ринок зерна й продуктів його переробки.

This work is licensed under a Creative Commons Attribution 4.0 International License http://creativecommons.org/licenses/by/4.0/

Постановка проблеми та її зв'язок з важливими науковими та практичними завданнями. Ефективне функціонування стратегічних товарних ринків передбачає максимізацію створення ринкової доданої вартості, яка є джерелом і головним ресурсом відтворювального розвитку національної економіки. В умовах обмеженості резерву зниження витрат суб'єктів ринку для нарощування доданої вартості першочергового значення набуває завдання ефективного використання логістичного потенціалу ринків. В Україні логістична складова в ВВП є досить високою - 30-35\%, тоді як в розвинених країнах вона складає $10-15 \%$ і менше [1]. Пошук шляхів скорочення логістичних витрат передбачає організацію ефективного товароруху в стратегічних ринках країни, дослідженням якого займається ринкова логістика.

На відміну від логістики підприємств (мікрорівень), орієнтованої на реалізацію економічних інтересів суб'єктів господарювання, логістика товарних ринків (макрорівень) базується на узгодженні інтересів суб'єктів ринку та держави, передбачає викори- стання відтворювального підходу до розбудови ефективних логістичних ланцюгів товарних ринків (далі ЛЛТР). Включення в систему економічних інтересів державного інтересу змінює мету ЛЛТР з максимізації прибутків великих суб'єктів, наділених ринковою владою, до реалізації логістичного потенціалу відтворювального розвитку ринку, оптимізації внутрішніх і зовнішніх товаропотоків у системі. Держава повинна виконувати функцію регулятора функціонування ЛЛТР, що обумовлює необхідність нових фундаментальних досліджень у напрямі ринкової логістики.

Аналіз останніх публікацій по проблемі. Теоретико-методологічні засади розвитку логістики підприємств висвітлені в працях учених О. П. Величко [2], О. Б. Гірної [3], Н. Ю. Глинського [3], Є. В. Крикавського [4], М.А. Окландера, Ю.В. Пономарьової [5], Н.І. Чухрай [6] та інших науковців. Новий напрям досліджень - логістики товарного ринку - започаткували учені Інституту проблем ринку та економіко-екологічних досліджень НАН України [7, 8]. Становлення ринкової логістики, як

* Публікацію підготовлено в межах виконання НДР «Формування ефективної логістики товарних ринків» (№ держреєстрації 0119U000227) 
науково-організаційного напрямку розвитку товарних ринків, обумовлює необхідність розробки ії теоретичного базису, у т.ч. логістичної будови ринку, типології зв'язків між його елементами, природи логістичної операції, що формує наукове підгрунтя для обгрунтування державної логістичної політики в ринковому вимірі.

Формулювання цілей дослідження. Мета статті - розробка теоретичних положень щодо формування логістичної структури товарного ринку та їх конкретизація шляхом емпіричних досліджень окреслила низку завдань:

1) визначення природи, структури, класифікації логістичних ланцюгів товарних ринків, взаємозв'язків між їх ланками;

2) обгрунтування закономірності багатофункціональної сутності логістичної операції на базі відтворювального підходу;

3) аналіз структури логістичного ланцюга ринку зерна та продуктів його переробки, трансформаційного впливу чинників на його розвиток.

Виклад основних результатів та їх обгрунтування. Логістична структура товарного ринку представляє собою впорядковану сукупність елементів (ланок) з переміщення матеріальних і пов'язаних 3 ними фінансових та інформаційних потоків на шляху від первинного джерела сировини до кінцевого споживача готової продукції. Йдеться про логістичний ланцюг товарного ринку. В теорії логістики учені оперують двома категоріями - ланцюг постачання й логістичний ланцюг, які є відображенням суб'єктного й процесного підходів відповідно. Ланками ланцюга постачання є окремі суб'єкти господарювання, а логістичного ланцюга - процеси забезпечення бізнесу. На думку О. П. Величко, ланцюг постачання - це поступове просування товарів у межах окремого матеріального потоку від первинного постачальника до кінцевого споживача. Логістичний ланцюг - це сукупність взаємопов'язаних послідовних і паралельних операцій (бізнес-процесів) з логістичного забезпечення процесу створення та доведення до споживача готової продукції, роботи або послуги [2, с. 30-31].

Такі визначення корелюють 3 розробками іноземних учених. Так, суб'єктний підхід до інтерпретації ланцюга постачання підтримують американські економісти; розгляд логістичного ланцюга як шлях від постачальників до споживачів через процес підтримують німецькі фахівці (саме це визначення наявне в одному з національних стандартів Німеччини) [9].

Враховуючи відтворювальну природу й мету логістичного ланцюга товарного ринку, авторське визначення категорії $є$ таким: лінійно впорядкована (оптимізована) сукупність ланок з переміщення матеріальних і пов'язаних з ними фінансових та інформаційних потоків на шляху від первинного джерела сировини до кінцевого споживача готової продукції, яка реалізує відтворювальну функцію товароруху в ринку. Логістична ланка представляє собою функціонально відокремлену типову складову ЛЛТР, яка виконує відповідне завдання в процесі відтворення товароруху в ринку: транспортування, складування, доро- бка, розподіл тощо.

Множина різних ЛЛТР формує логістичну систему національної економіки. Є. Крикавський визначає логістичну систему як цільову інтеграцію логістичних елементів у межах певної системи $з$ метою оптимізації процесів трансформації матеріального потоку. За інституціональною ознакою логістичні системи учений поділяє на такі види: мікрологістичні (підприємства), металогістичні (логістичні ланцюги), мезо- й макрологістичні, зовнішні логістичні системи (міжсистеми) [4].

Властивості систем у логістичних ланцюгах виявляють певну специфіку. Цілісність означає, що ЛЛТР може бути виділений зі свого економічного простору як самостійна система, яка має власні цілі функціонування і розвитку. Разом $з$ тим логістичний ланцюг може бути поділений на елементи - ланки й логістичні операції. Між елементами ланцюга існують зв'язки, що з'єднують ланки в логістичному процесі. Зв'язки забезпечують виникнення та збереження цілісних властивостей логістичного ланцюга, характеризують як його будову, так i функціонування. ЛЛТР як єдине ціле існує саме завдяки наявності зв'язків між його складовими. Ці зв'язки визначають інтегративні якості системи, і тому повинні бути більш потужними, ніж зв'язки окремих елементів із зовнішнім середовищем.

Зв'язки і взаємодії між ланками формують структуру ЛЛТР. Термін «структура» (лат. structura) характеризує будову, розташування, порядок, взаємозв'язок складових. Структуру логістичного ланцюга товарного ринку можна трактувати як відносно постійний порядок внутрішніх просторових зв'язків ланцюга між його ланками та їх взаємодію як у межах ланцюга, так із зовнішнім середовищем для реалізації відтворювальної функції товароруху в ринку. У практичному вимірі структура ЛЛТР представляє собою організовану сукупність ланок, через які матеріальні і пов'язані з ним фінансові та інформаційні потоки проходять під час свого переміщення від первинного постачальника до кінцевого споживача продукції. Структуризація ринкових логістичних ланцюгів дозволяє досліджувати ефективність функціонування як кожної ланки, так і ланцюга в цілому, визначати логістичні «розриви» в товаропотоках, обгрунтовувати управлінські рішення щодо їх нівелювання, підвищення ефективності роботи як окремих ланок, так i ланцюга в цілому.

Для побудови структури ЛЛТР принципове значення має визначення природи й спрямування зв'язків між ланками. У логістичних ланцюгах зв'язки між ланками мають низку специфічних проявів, які дають підставу для обгрунтування типології зв'язків. У залежності від характеру та форм прояву зв'язків у ЛЛТР можна виділити 7 їх типів, а саме: зв'язки взаємодії, утворення, трансформації, будови, функціонування, розвитку та управління. Найбільш широким типом є зв'язки взаємодії, які в певній мірі присутні у всіх інших видах зв'язків. У ринкових логістичних ланцюгах зв'язки взаємодії встановлюються процесами управління матеріальними та пов'яза- 
ними 3 ним фінансовими, інформаційними й сервісними потоками.

Базовим видом зв'язків взаємодії, який складає основу побудови логістичних ланцюгів товарних ринків і формує їх структуру, є господарський зв'язок. У контексті системної організації ринкової логістики серед усіх видів зв'язків взаємодії центральне місце займає господарський зв'язок, як спосіб взаємодії суб'єктів ринку, держави та населення з приводу виробництва, розподілу, обміну та споживання товару. Становлення та розвиток ефективних форм взаємодії учасників потокового процесу є необхідною умовою досягнення головної мети ЛЛТР - розширене відтворення ресурсів у його ланках.

В теорії логістики господарські зв'язки поділяють на два види [5, 6]: (1) прямі зв'язки, які утворюються між суб'єктами ринку, державою, споживачами; (2) опосередковані зв'язки, що формуються за участю посередницьких організацій. За системної організації ринкової логістики учасниками логістичних ланцюгів стають логістичні оператори - посередники, які надають різноманітні логістичні послуги.
Враховуючи базові принципи ринкової логістики [7], автором розроблено класифікацію логістичних ланцюгів товарних ринків (таблиця 1).

Логістичні ланцюги в залежності від територіальних (географічних) меж товарного ринку можуть бути внутрішніми й зовнішніми. У свою чергу, внутрішні ЛЛТР поділяються на локальні (територія певного району, міста), регіональні й державні. Слід відзначити, що з розширенням товарних меж ринку змінюється логістика міжланкових відносин. Так, у локальних ЛЛТР існуючі умови для узгодження наскрізних характеристик товарних потоків не мають вирішального значення у відтворювальному процесі (один вид транспорту, малі обсяги постачань, обмежена товарна номенклатура тощо). Водночас у державних ЛЛТР роль інтеграційної компоненти у збалансуванні міжланкових відносин суттєво посилюється. Провідними областями узгодження потоків постають збірні поставки, наскрізні тарифи, механізми взаємодії різних видів транспорту, наявність загальних розподільчих центрів тощо [8].

Класифікація логістичних ланцюгів товарних ринків *

Таблиця 1

\begin{tabular}{|c|c|}
\hline Ознаки класифікації & Види ринкових логістичних ланцюгів та їх характеристика \\
\hline $\begin{array}{l}\text { 1. Географічні (тери- } \\
\text { торіальні) межсі то- } \\
\text { варного ринку }\end{array}$ & $\begin{array}{l}\text { 1. Внутрішні - формуються в географічних (територіальних) межах держави. У } \\
\text { залежності від територіальної ознаки внутрішні ЛЛТР можуть бути локальними, } \\
\text { регіональними та державними. } \\
\text { 2. Зовнішні - територія формування та функціонування ланок ринкового логістич- } \\
\text { ного ланцюга виходить за межі держави. Йдеться про світові (глобальні) логістичні } \\
\text { ланцюги товарних ринків }\end{array}$ \\
\hline $\begin{array}{l}\text { 2. Розподіл впливу } \\
\text { суб'єктів ринку } \\
\text { (ринкових сил) }\end{array}$ & $\begin{array}{l}\text { 1. Логістичні ланцюги, «мотивовані виробником» (producer-driven) - створюються } \\
\text { у високотехнологічних секторах (виробництві напівпровідників, електроніки, авто- } \\
\text { мобільній та фармацевтичній промисловості). } \\
\text { 2. Логістичні ланцюги, «мотивовані покупцем» (buyer-driven) - формуються навко- } \\
\text { ло великих підприємств роздрібної торгівлі, орієнтовані на виробництво переважно } \\
\text { споживчих товарів (одяг, текстиль, взуття, господарські товари тощо). }\end{array}$ \\
\hline $\begin{array}{l}\text { 3.Організаційно- } \\
\text { правова форма } \\
\text { суб'єктів ланцюга }\end{array}$ & $\begin{array}{l}\text { 1. Корпоративні логістичні ланцюги - послідовні етапи постачання, виробництва й } \\
\text { розподілу товарів знаходяться в межах одно- чи декілька осібного контролю. } \\
\text { 2. Кооперативні логістичні ланцюги - послідовні етапи постачання, виробництва й } \\
\text { розподілу товарів контролюються через демократичне управління та багатоосібне } \\
\text { рівноправне співволодіння. }\end{array}$ \\
\hline $\begin{array}{l}\text { 4. Спрямованість ру- } \\
\text { ху матеріального по- } \\
\text { току }\end{array}$ & $\begin{array}{l}\text { 1. Логістичні ланцюги з прямими зв 'язками, в яких керований матеріальний потік } \\
\text { рухається в одному напрямку. } \\
\text { 2. Логістичні ланцюги зі зворотним зв 'язком, в яких переміщуються зворотні мате- } \\
\text { ріальні потоки (рух відновлювальних матеріальних об'єктів, наприклад, запасних } \\
\text { частин, переробка відходів виробництва). } \\
\text { 3. Логістичні ланцюги з комбінованими зв'язками, які включають альтернативні } \\
\text { траєкторії руху матеріального потоку, в т.ч. що дублюють один одного. }\end{array}$ \\
\hline $\begin{array}{l}\text { 5. Відтворювальна } \\
\text { спроможсність }\end{array}$ & $\begin{array}{l}\text { 1. Високорозвинений ЛЛТР - орієнтований на виробництво та розподіл товару кін- } \\
\text { цевого споживання з максимальною доданою вартістю. } \\
\text { 2. Середньорозвинений ЛЛТР - містить у своїй структурі недостатньо розвинені } \\
\text { ланки, діяльність яких не забезпечує максимізацію доданої вартості у ринковому } \\
\text { ланцюгу. } \\
\text { 3. Нерозвинений ЛЛТР - відсутність однієї або декількох ланок у структурі ланцю- } \\
\text { га, що продукує втрати доданої вартості в системі. }\end{array}$ \\
\hline
\end{tabular}

розроблено автором із використанням джерел $[5,6,8,10]$. 
За ознакою розподілу ринкових сил, залежно від ролі транснаціональних корпорацій і незалежних постачальників, ринкові логістичні ланцюги (передусім, зовнішні) поділяють на «мотивовані виробником» (producer-driven) та «мотивовані покупием» (buyer-driven) (див. табл. 1). Для першого типу ЛЛТР притаманні висока фрагментація виробничого процесу, збірка високотехнологічної продукції у кількох країнах, контроль процесу провідним підприємством, впровадження науково-технічних розробок. Головна компанія у ланцюгах другого типу, як правило, зосереджує свою діяльність на маркетингу, володіє невеликою кількістю власних виробничих підприємств, однак має розгалужену мережу незалежних постачальників [10, с.24-25].

За організаційно-правовою формою суб'єктів (учасників) ланцюгів виділяють корпоративні й кооперативні ЛЛТР (див. табл. 1). Незважаючи на спільний цільовий орієнтир - контроль ринкового логістичного ланцюга - метою корпоративних ланцюгів $є$ максимізація прибутків, метою кооперативних ланцюгів - мінімізація логістичних витрат членів кооперативу. Виділені типи логістичних ланцюгів притаманні, передусім, внутрішнім аграрним ринкам.

За спрямованістю руху матеріального i пов'язаних з ним фінансового та інформаційного потоків ринкові логістичні ланцюги доцільно розділити на три види: ЛЛТР з прямими, зворотними та комбінованими зв 'язками.

За ознакою відтворювальної спроможності ми пропонуємо виокремити три типи ринкових логістичних ланцюгів (див. табл. 1). У високорозвинених ЛЛТР здійснюється процес виробництва, розподілу та споживання товару кінцевого споживання, що забезпечує максимізацію доданої вартості в ринку та реалізацію економічних інтересів держави. У структурі середньорозвинених ЛЛТР функціонують недостатньо ефективні ланки, які мають потенціал нарощування доданої вартості за умови цілеспрямованого впливу держави. Нерозвинені ЛЛТР характеризуються відсутністю однієї або декількох логістичних ланок, що продукує втрати доданої вартості в системі. Формування ефективної логістики товарних ринків передбачає формування множини високорозвинених ЛЛТР та їх взаємодій між собою для відтворювального розвитку національної економіки.

Оскільки головним ресурсом і джерелом економічного зростання держави є додана вартість, розглянемо більш детально процес продукування іiі логістичної складової в ланках ринкового ланцюга. Додана вартість товару формується в процесі здійснення логістичної операції, яка представляє собою відособлену сукупність дій, орієнтовану на перетворення матеріального потоку. Логістична операція являє собою завершену дію в межах ланки ЛЛТР, яка не спроможна до подальшого розукрупнення. Основою дослідження логістичної природи доданої вартості $\epsilon$ логістична операція, яка забезпечує перехід (трансформацію) матеріального потоку із одного стану в інший, що супроводжується зміною вартісних, часових i просторових параметрів товарообмінної операції.

У залежності від ознаки переходу права власності на товар логістичні операції поділяються на односторонні й двосторонні (рис. 1).

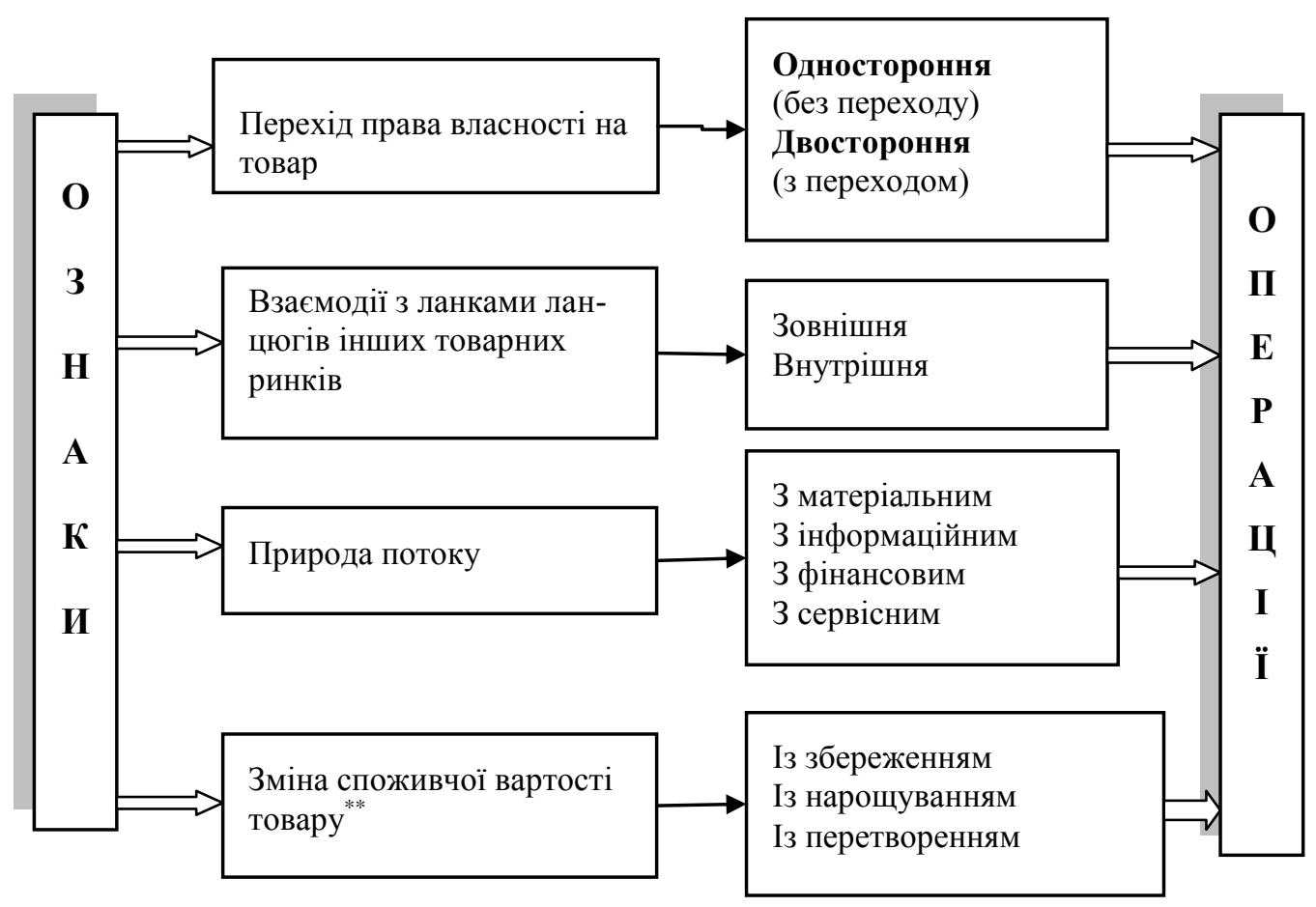

Рис.1. Класифікація логістичних операцій у ланцюгах товарних ринків * розроблено автором із використанням джерел [4, 5];

** запропоновано автором 
Логістичні операції, виконувані шляхом взаємодії ланок ланцюгів різних товарних ринків (наприклад, у ході постачання матеріалів і сировини для виробництва товарів релевантного ринку), називаються зовнішніми; логістичні операції, виконувані всередині ланцюга одного товарного ринку, є внутрімніми. У залежності від природи потоку можна виділити логістичні операції з матеріальним, інформаційним та фінансовим потоком. Деякі учені ідентифікують четвертий вид потоку - сервісний (поток послуг).

Традиційну класифікацію логістичних операцій ми пропонуємо доповнити ознакою зміни споживчої вартості товару (далі - СВТ), за якою можна виділити три види операцій (див. рис. 1): (1) із збереженням СBT; (2) із нарошуванням CBT; (3) із перетворенням $C B T$. Перший вид логістичних операцій $€$ домінуючим у ринкових логістичних ланцюгах, він передбачає збереження якісних параметрів і корисних властивостей товару у процесі його руху від первинного джерела сировини до кінцевого споживача готової продукції. Нарощування СВТ відбувається в ході здійснення операцій із доробки товару, яка покращує його корисні властивості. Перетворення СВТ передбачає трансформацію матеріального потоку у товар із новими споживчими властивостями (наприклад, переробка відходів у енергетичний ресурс). При цьому логістична компонента доданої вартості, ресурсну структуру якої формують прибуток і заробітна плата працівників, зростає в ході реалізації логістичних операцій як із збереженням, так із нарощуванням та перетворенням споживчої вартості товару. Дана авторська позиція дещо відрізняється від класичних концепцій логістики.

Концепція Value added logistics (логістика доданої вартості) базується на такому твердженні: будьяка логістична операція додає вартість товару або послузі, однак нарощування вартості ще не означає додавання цінності (корисності) з позиції споживача. При цьому нарощування доданої вартості відбувається за рівня логістичного сервісу, вищого базового. Концепція логістики доданої вартості визначає логістичний сервіс як процес створення істотних вигод, що містять додану вартість, у логістичному ланцюгу найбільш ефективним, з точки зору споживача, способом [6]. Відтак, в основі цієї концепції лежить поділ логістичних операцій на базові й вищі за базові; саме останні спроможні продукувати додану вартість у логістичному ланцюгу.

Деякі учені у складі логістичної операції пропонують виокремити основні процеси, які забезпечують створення доданої вартості, та допоміжні, що взаємопов'язані з основними процесами, але додану вартість не створюють [8].

У контексті логістичного підходу учені виділяють додану вартість двох типів: для споживача (клієнта) і підприємства. Головним є клієнтоорієнтований підхід, оскільки саме клієнт є останньою ланкою ланцюга поставок. Дана ланка $є$ результатом створення цінності на протязі усього ланцюга поставок. В такий спосіб вона стає мірою оцінювання про- цесу формування цінності, метою якої є пропонування клієнтові відчутної корисності. Додана вартість для підприємства пов'язана із його корисностями, які визначаються різницею між ціною продажу та рівнем понесених витрат [3, с. 43-44; 11, с. 28-29].

В економічній літературі трактування поняття «вартість» $є$ двохвимірним: по-перше, як виражена цінність або корисність певного блага; по-друге, як виражена в фінансах величина витрат на створення цієї цінності. Виходячи 3 цього, ми пропонуємо не ототожнювати, а чітко виділяти два види вартості споживчу й додану - в процесі товароруху за ланками ЛЛТР. Споживча вартість формує речовий зміст товару, а додана вартість - кількісний. Такий розподіл $€$ важливим у контексті розробки методичного забезпечення до оцінки ефективності функціонування певних ланок і усього ринкового логістичного ланцюга 3 використанням показника доданої вартості, що має кількісний вимір.

У межах логістичного ланцюга товарного ринку доцільно виділити ланкову і ринкову додану вартість. Ланкова додана вартість створюється в процесі виробництва (надання послуг) та переміщення товарів суб'єктами господарювання певної ланки (постачання матеріальних ресурсів, виробництво продукції, іiі складування, доробка, розподіл, реалізація та ін.), що відображає реальний внесок даної ланки у формування вартості товару (послуги) в ринку. Ринкова додана вартість включає суму новостворених вартостей кожної ланки логістичного ланцюга товарного ринку.

Таким чином, проведені дослідження природи логістичної компоненти вартості товару дозволяють обгрунтувати закономірність багатофункиіональної сутності логістичної операчії, яка полягає у збереженні, нарощуванні та перетворенні споживчої вартості товару у процесі його руху за ланками логістичного ланцюга товарного ринку від первинного джерела сировини до кінцевого споживача готової продукції та переробки відходів, що супроводжується зростанням ринкової доданої вартості.

Встановлену закономірність відображає табл. 2 шляхом ідентифікації напрямів змін споживчої й доданої вартості товару у структурних ланках ЛЛТР. На фоні стабільного зростання доданої вартості товару в процесі його руху за ланками ринкового логістичного ланцюга відбувається, передусім, збереження споживчої вартості товару; саме ця процедура є однією 3 базових функцій ринкової логістики. Зростання СВТ відбувається в процесі доробки товару, його сортування й пакування, що підвищує корисність продукту 3 точки зору споживача. Перетворення СВТ передбачає формування нових споживчих властивостей нового товару, а саме: у ланці виробництва - продукту переробки сировинних ресурсів; у ланці утилізації й переробки відходів - енергетичних ресурсів тощо. Наявність у складі ланок логістичних операцій з виробництва й доробки товару, які збільшують його споживчу вартість, сприяє нарощуванню ринкової вартості за рахунок якісного перетворення матеріального потоку. 
Таблиця 2

Напрями зміни споживчої й доданої вартості товару у ринковому логістичному ланцюгу*

\begin{tabular}{|l|c|c|c|c|c|c|}
\hline \multirow{2}{*}{$\begin{array}{c}\text { Вартість } \\
\text { товару }\end{array}$} & \multicolumn{5}{|c|}{ Головні ланки логістичного ланцюга товарного ринку } \\
\cline { 2 - 7 } & $\begin{array}{c}\text { Постачання } \\
\text { матеріалів }\end{array}$ & $\begin{array}{c}\text { Виробництво } \\
\text { товару }\end{array}$ & $\begin{array}{c}\text { Складування, } \\
\text { транспорту- } \\
\text { вання }\end{array}$ & $\begin{array}{c}\text { Доробка } \\
\text { сортування } \\
\text { пакування }\end{array}$ & $\begin{array}{c}\text { Розподіл } \\
\text { Реалізація }\end{array}$ & $\begin{array}{c}\text { Утилізація, } \\
\text { переробка } \\
\text { відходів }\end{array}$ \\
\hline $\begin{array}{l}\text { 1.Споживча } \\
\text { вартість }\end{array}$ & Збереження & Перетворення & Збереження & Зростання & Збереження & Перетворення \\
\hline $\begin{array}{l}\text { 2.Додана } \\
\text { вартість }\end{array}$ & Зростання & Зростання & Зростання & Зростання & Зростання & Зростання \\
\hline
\end{tabular}

*авторська розробка

Структурна будова логістичного ланцюга, його тип, кількість ланок, сукупність зв'язків і взаємодій між ними, склад логістичних операцій у межах ланок та інші логістичні параметри визначаються специфікою процесів відтворення певних товарних ринків та множиною внутрішніх і зовнішніх чинників впливу на їх стан. Особливості структури й специфікації ринкового логістичного ланцюга та зв'язків між його ланками розглянемо на прикладі українського ринку зерна та продуктів його переробки. Логістичний ланцюг даного ринку представлений на рис. 2.

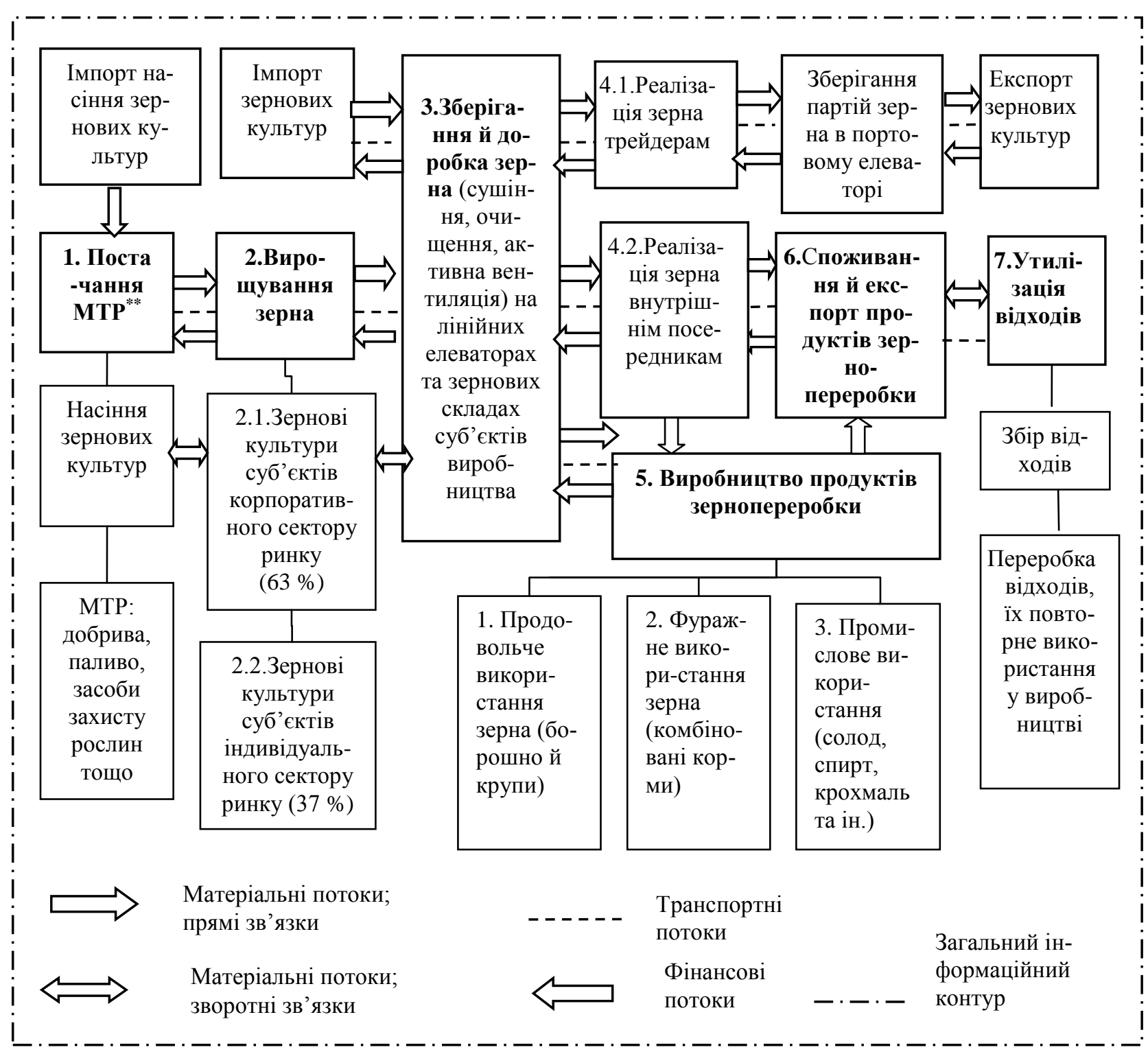

Рис. 2. Логістичний ланцюг українського ринку зерна та продуктів його переробки*

*авторська розробка;

**МТР - матеріально-технічні ресурси. 
Структурну архітектуру логістичного ланцюга ринку зерна та продуктів його переробки формують 7 базових ланок (див. рис. 2). Перша ланка - постачальницька - забезпечує виробників необхідними для вирощування зерна матеріально-технічними ресурсами і насінням культур, у т.ч. імпортованим. Друга ланка - аграрна - спеціалізується на вирощуванні зернових культур. Сьогодні суб'єкти корпоративного сектору ринку (великі сільгосппідприємства) виробляють близько 63 \% культур, в основному експортоорієнтованих, що визначає зовнішню спрямованість їх матеріального потоку. Водночас суб'єкти індивідуального сектору ринку (фермерські й особисті селянські господарства) вирощують близько $37 \%$ зерна, переважно для внутрішнього споживання, що визначає домінуючу внутрішню спрямованість їх матеріального потоку.

Третя ланка ЛЛТР передбачає зберігання та доробку зерна шляхом його очищення, сушіння, вентиляції тощо (див. рис. 2). Саме у цій ланці після визначення діючими на елеваторах лабораторіями якісних параметрів, типу і класу зерно набуває товарності і вартісної оцінки. Великі аграрні підприємства, як правило, зберігають культури на лінійних елеваторах, що дає їм можливість реалізації товару в період сприятливої цінової кон'юнктури.

Слід відзначити наявність зворотних зв'язків між суб'єктами корпоративного сектору зернового ринку та ланкою зберігання й доробки зерна, з одного боку, і насінницькою ланкою, з іншого, що є свідченням формування власного корпоративного логістичного ланиююга, орієнтованого на реалізацію економічних інтересів великих інтегрованих структур. У такому ланцюгу малі й середні зерновиробники завжди будуть нести втрати через нерівноправність економічних відносин між різними суб'єктами. Її проявом на практиці є штучне заниження цін на продукцію індивідуальних зернових господарств, необ'єктивне визначення класів зерна приватними елеваторами, завищені тарифи на зернозберігаючі послуги тощо. Як наслідок, більшість суб'єктів індивідуального сектору ринку відмовляється від послуг монопольних елеваторів, зберігає вирощене зерно й насіння на власних складах, використовуючи певну його частину для внутрішнього споживання, передусім кормового.

Відтак, у межах аграрної ланки індивідуального сектору ринку формується своєрідний мікрологістичний ланцюю: насіння - зерно — зберігання фуражне споживання. Зберігання зерна в непристосованих складах супроводжується зниженням його якісних параметрів, відтак, у даному мікроланцюгу логістична операція неспроможна не тільки наростити, але й зберегти СВТ. Втрата базових функцій логістичної операції $є$ свідченням неефективності такої ланки ланцюга. Відторгнення аграрної ланки індивідуального сектору від взаємодій із іншими ланками корпоративного ланцюга зернового ринку, зокрема, ланкою зберігання й доробки товару, формує передумови до розбудови кооперативних логістичних ланцюгів у регіонах України.
Четверта ланка - розподілу та реалізації зерна - передбачає три головні напрями товароруху: (1) реалізація культур трейдерам для їх подальшого експорту; (2) збут зерна внутрішнім посередникам, які потім здійснюють його продаж переробникам; (3) реалізація культур безпосередньо переробним підприємствам (див. рис. 4). При цьому до розподільчої ланки матеріальний потік може рухатися як із третьої ланки зберігання й доробки зерна, так і безпосередньо із аграрної ланки. Наявність таких альтернативних траєкторій руху матеріального потоку є свідчення комбінованого типу логістичного ланцюга ринку зерна та продуктів його переробки.

За статистичними даними, у структурі реалізації зерна аграрними підприємствами 90,5 \% припадає на посередницькі «інші канали», 4 \% населенню в рахунок оплати праці, 2,2 \% - на ринку і всього лише 3,3\% - переробним підприємствам [12]. У 1990 р. переробний збутовий канал був головним, охоплюючи 80,4 \% зерна, вирощеного сільгосппідприємствами. Сьогодні домінує непрозорий посередницький канал, що генерує значні втрати як для індивідуальних зерновиробників, так і держави.

Відтак, урізноманітнення каналів реалізації зерна, спрямування товарного потоку із непрозорого «іншого» до переробного каналу $є$ важливим завданням держави на шляху розбудови ефективної логістики стратегічного зернового ринку.

У п'ятій ланці в процесі перетворення споживчої вартості виробляються нові товари із новими властивостями, які можна розділити за трьома напрямами використання (споживання) зерна: (1) продовольче; (2) фуражне; (3) промислове (див. рис. 2). Кількісні пропорції розподілу товаропотоків ілюструє баланс зернового споживання (таблиця 3). Згідно його даних, у 2017 р. обсяги продовольчого й фуражного використання зерна склали 5,66 млн. т і 11,01 млн. т, що на $36,1 \%$ i 40,6\% менше рівня 1995 р. відповідно; обсяги промислового зернового споживання досягли 1,25 млн. т, збільшившись порівняно з 1995 р. на 42,2 \% (на 0,37 млн. т). Загалом у звітному році обсяг зернового потоку, що надійшов до переробних ланок ринкового логістичного ланцюга, склав 17,91 млн. т. Водночас обсяг експортного товаропотоку досягнув 42,5 млн. т, перевищивши рівень внутрішньої переробки зерна в 2,4 рази.

Аналіз структурно-динамічних змін у зерновому споживанні за 20-річний період дозволяє визначити трансформації, які впливали на напрям товароруху та ефективність логістичного ланцюга зернового ринку у різні проміжки часу. Так, у 1995 р. у структурі загального споживання зерна сукупна частка переробки зерна складала $81 \%$, частка експорту $-2,3 \%$, що $\epsilon$ свідченням спрямування більшості зернових потоків до переробної ланки. Такі структура і маршрут товароруху забезпечували розширене відтворення ресурсів і формували високорозвинений логістичний ланцюг ринку зерна та продуктів його переробки. 
Таблиця 3

Структурно-динамічні зміни у зерновому споживанні в Україні*

\begin{tabular}{|c|c|c|c|c|c|c|c|c|c|}
\hline \multirow{2}{*}{ Показники } & \multicolumn{2}{|c|}{1995} & \multicolumn{2}{|c|}{2005} & \multicolumn{2}{|c|}{2015} & \multicolumn{2}{|c|}{2017} & \multirow{2}{*}{$\begin{array}{l}2017 \mathrm{p} . \mathrm{y} \% \\
\text { до } 1995 \text { p. }\end{array}$} \\
\hline & млн. т & $\%$ & млн. т & $\%$ & млн. т & $\%$ & млн. т & $\%$ & \\
\hline 1.Валовий збір & 33,93 & $\bar{X}$ & 38,02 & $\bar{X}$ & 60,13 & $\bar{X}$ & 61,92 & $\bar{X}$ & 182,5 \\
\hline $\begin{array}{l}\text { 2.Загальне спожи- } \\
\text { вання зерна, у т.ч.: }\end{array}$ & 34,89 & 100,0 & 38,56 & 100,0 & 63,51 & 100,0 & 63,64 & 100 & 182,4 \\
\hline 2.1.Насіннєвий фонд & 4,60 & 13,2 & 3,29 & 8,5 & 2,60 & 4,1 & 2,12 & 3,3 & 46,1 \\
\hline 2.2. Продовольче & 8,85 & 25,4 & 7,75 & 20,1 & 5,90 & 9,3 & 5,66 & 8,9 & 63,9 \\
\hline 2.3. Кормове & 18,53 & 53,1 & 13,82 & 35,8 & 14,19 & 22,3 & 11,01 & 17,3 & 59,4 \\
\hline 2.4. Промислове & 0,88 & 2,5 & 0,67 & 1,7 & 1,09 & 1,7 & 1,25 & 2,0 & 142,2 \\
\hline 2.5. Втрати & 1,22 & 3,5 & 0,38 & 1,0 & 1,40 & 2,2 & 1,11 & 1,7 & 90,7 \\
\hline 2.6. Експорт & 0,81 & 2,3 & 12,65 & 32,8 & 38,34 & 60,4 & 42,50 & 66,8 & y $5,2 \mathrm{p}$ \\
\hline $\begin{array}{l}\text { 3. Експорт у \% до } \\
\text { валового збору }\end{array}$ & 2,40 & $X$ & 33,28 & $X$ & 63,76 & $X$ & 68,64 & $X$ & $\mathrm{X}$ \\
\hline
\end{tabular}

*розраховано автором за даними Державної служби статистики України [13, с.40]

Починаючи з 2000 р. структура зернового споживання змінювалася у бік нарощування експорту за рахунок скорочення внутрішнього використання зерна, що, в свою чергу, впливало на напрям і обсяги товароруху, структуру та зв'язки між ланками ринкового логістичного ланцюга. Так, у 2005 р. у структурі загального споживання частка переробки зерна складала $57,7 \%$, частка експорту - 32,8 \% (див. табл. 3), що є свідченням перерозподілу (через посередницькі «інші канали») частини товаропотоків 3 переробної до експортної ланки ланцюга. Така зміна маршруту товароруху обумовила втрати доданої вартості в переробній ланці, знизила іï ефективність, змінила тип ринкового логістичного ланцюга 3 високо- до середньорозвиненого.

У 2015-2017 рр. відбувається постійне нарощування обсягів зернового експорту, що поглиблює структурні дисбаланси у використанні зерна. У 2017 р. в структурі загального споживання частка переробки зерна складала $28,2 \%$, частка експорту $66,8 \%$ (див. табл. 3). За вказаний період частка кормового споживання зменшилася 322,3 \% до 17,3\%, що пов'язано, зокрема, зі скороченням поголів'я тварин (у 2017 р. порівняно з 2000 р. поголів'я великої рогатої худоби зменшилося на $62 \%$, у т.ч. корів - на $59 \%$ [12]). Збереження такої тенденції за умови відсутності ефективних заходів держави у напрямі переорієнтації агроекспорту 3 сировини на продукти іiі переробки призведе до мінімізації товарообігу в переробній ланці та перетворення логістичного ланцюга зернового ринку у нерозвинений, незважаючи на потужний потенціал його відтворювального розвитку в Україні.

Шоста ланка - споживча - передбачає рух товаропотоків зернопродуктів для кінцевого споживання населенням та промислового споживання (наприклад, борошно використовується в хлібопекарській і кондитерській промисловості для виробництва товарів із новою споживчою вартістю) (див. рис. 2). Незначна частина зернопродуктів надходить на зовнішні ринки збуту. У структурі загального вітчизняного експорту частка борошномельно-круп'яної продукції складає всього 0,4 \%, частка зерна - 15-15,3 \% (20172018 pp.) [12].

Обсяги товаропотоків, що надходять у заключну ланку ринкового логістичного ланцюга, орієнтовану на збір і переробку відходів, є незначними й мають тенденцію до скорочення. За статистичними даними, в 2017 р. в Україні було утилізовано 100,06 млн. тонн відходів, що на 31,3 \% менше рівня 2010 р. При цьому сумарна частка утилізованих і спалених відходів в обсязі утворених відходів досягла 27,6 \%, що на 6,8 \% нижче показника 2010 р [12].

Сучасний стан ланки утилізації відходів у ЛЛТР є незадовільним. Ефективне функціонування даної ланки передбачає впровадження комплексу заходів поводження 3 відходами. Застосування сучасних технологій і практик поводження 3 відходами, збільшення обсягу переробки відходів та їх повторного використання формують підгрунтя для впровадження моделі циркулярної економіки, орієнтованої на розбудову відновлювальних та замкнених ланцюгів «take, make, reuse» («взяти, зробити, використати повторно»), що забезпечують максимізацію ринкової доданої вартості.

Висновки та перспективи подальших досліджень. Таким чином, проведене емпіричне дослідження структурної будови, зв'язків між ланками та сучасних трансформацій логістичного ланцюга українського ринку зерна та продуктів його переробки дозволили конкретизувати теоретичні положення ринкової логістики, викладені вище.

За географічними межами логістичний ланцюг зернового ринку є зовнішнім, однак у даному дослідженні проведено аналіз ЛЛТР у державному вимірі 3 акцентом на внутрішні проблеми його розвитку. В Україні домінують корпоративні ринкові ланцюги, тоді як в розвинених аграрних країнах - кооперативні. За спрямованістю руху матеріального потоку логістичний ланцюг ринку зерна та продуктів його переробки належить до комбінованого типу, для якого притаманні альтернативні траєкторії руху товаропо- 
токів, множина прямих і зворотних зв'язків. За відтворювальною спроможністю даний ринковий ланцюг $\epsilon$ середньорозвиненим із перспективою трансформації в нерозвинений за умови нарощування сировинного експорту. ринку формують 7 базових ланок, з них дві (переробна й утилізації відходів) є малоефективними, з незначними обсягами товаропотоків. Перетворення СВТ відбувається в ланках вирощування зерна, виробництва зернопродуктів, переробки відходів, нарощування CВТ - в ланці доробки зерна. В інших ланках ринкового ланцюга логістичні операції виконують функцію збереження споживчих якостей товару. Між ланками логістичного ланцюга зернового ринку переважають зв'язки взаємодії та функціонування, мають місце як прямі, так і опосередковані зв'язки.

На практиці внаслідок неузгодженості економічних інтересів індивідуальних зерновиробників та великих корпоративних структур і елеваторів у межах аграрної ланки індивідуального сектору ринку сформувався власний мікрологістичний ланцюг. Налагодження його взаємодій із ланкою зберігання й доробки товару передбачає розбудову кооперативних ринкових ланцюгів, які зможуть конкурувати 3 корпоративними ланцюгами. Визначені у ході дослідження неефективні ланки логістичного ланцюга ринку зерна та продуктів його переробки $є$ потенційними об’єктами державного селективного регулювання.
Структуру логістичного ланцюга зернового

Наукова новизна проведеного дослідження полягає в розробці теоретичних положень щодо формування логістичної структури товарного ринку в частині визначення його відтворювальної природи, типології зв'язків, класифікації ринкових логістичних ланцюгів та логістичних операцій. Також на базі відтворювального підходу вперше обгрунтовано закономірність багатофункціональної сутності логістичної операції, яка полягає у збереженні, нарощуванні та перетворенні споживчої вартості товару у процесі його руху за ланками логістичного ланцюга товарного ринку від первинного джерела сировини до кінцевого споживача готової продукції та переробки відходів, що супроводжується зростанням ринкової доданої вартості. Теоретичне значення результатів дослідження полягає в розвитку теоретичного базису ринкової логістики, як нового напрямку логістичної науки, практичне значення визначається можливістю використання авторських розробок управлінськими органами влади в ході визначення структури логістичних ланцюгів стратегічних товарних ринків, оцінки логістичних «розривів» i неефективних ланок, що формує наукове підгрунтя для розробки державної логістичної політики в ринковому вимірі. Перспективи подальших досліджень полягають у поглибленні теоретичного базису ринкової логістики, розширенні класифікації логістичних ланцюгів і операцій за рахунок нових базових ознак, конкретизації теоретичних розробок на прикладі стратегічних товарних ринків.

\section{Література}

1. Смирнов І.Г. Світовий ринок логістичних послуг: географічні особливості // Вісник Київського університету. Вип. 46. 2009. С. 60-65.

2. Величко О. П. Сутність логістичного ланцюга та його контроль сучасними агрохолдингами // Вісник соціально-економічних досліджень. 2012. Вип.3 (46), ч. 2. С. 27-33.

3. Гірна О. Б., Глинський Н.Ю., Кобилюх О.Я. Формування доданої вартості для клієнта в ланцюгу поставок // Логістика: теорія та практика. 2012. № 1(2). С. 39-46.

4. Крикавський Є. В., Чорнописька Н.В. Логістичні системи: навч. посібник. Львів: Вид-во Нац. ун-ту «Львівська політехніка», 2009. - 264 с.

5. Пономарьова Ю.В. Логістика: вид. 2-ге, перероб. та доп. К.: Центр навчальної літератури, 2005. $328 \mathrm{c.}$

6. Чухрай Н. І., Гірна О.Б. Формування ланцюга поставок: питання теорії та практики: монографія / Львів: «ннтелект-Захід», 2007. 232 с.

7. Логістика товарного ринку: монографія / за ред. Б. В. Буркинського, В. М. Лисюка. Одеса: ІПРЕЕД НАН України, 2018. 244 с.

8. Тараканов М.Л., Маковєєв А.П. Логістичний фактор формування доданої вартості в системі товарних ринків // Економіка: реалії часу. 2015. №2 (18). С.28-34.

9. Die logistische Kette / Prof. Dr. Heinz-Michael Winkels. - Essen. Januar 2000. URL: http://www.fhdowinkels.de/Logistikmanagement/ (date of treatment 05.04.2019).

10. Резнікова Н.В., Іващенко О.А. Перспективи участі України в глобальних ланцюгах створення вартості як засіб підвищення конкурентоспроможності в умовах транснаціоналізації виробничих відносин // Інвестиції: практика та досвід. 2015. №16. С.22-26.

11. Ciesielski M., Dlugosz J, Fuks K. I in. Zarzadzanie lancuchami dostaw. Pod red. naukowa M. Ciesielskiego. Warszava: PWE, 2011. $190 \mathrm{~s}$.

12. Офіційний сайт Державної служби статистики України. URL: http://www.ukrstat.gov.ua/ (дата звернення 05.04.2019).

13. Баланси та споживання основних продуктів харчування населенням України: статистичний збірник / Відп. за випуск О.М. Прокопенко. К.: Державна служба статистики України, 2018, 59 с.

Стаття надійшла 9.04.2019

Стаття прийнята до друку 23.04.2019 Доступно в мережі Internet 5.07.2019 


\author{
Никишина О.В. \\ доктор экономических наук, старший научный сотрудник \\ заведующий отдела рыночных механизмов и структур \\ Институт проблем рынка и экономико-экологических исследований НАН Украины \\ Французский бульвар, 29, г.Одесса, Украина, 65044 \\ E-mail: ksenkych@gmail.com \\ ORCID ID: 0000-0002-7172-3551
}

\title{
ЛОГИСТИЧЕСКАЯ СТРУКТУРА ТОВАРНОГО РЫНКА: ТЕОРЕТИЧЕСКИЕ ПОЛОЖЕНИЯ И ПРИКЛАДНЫЕ АСПЕКТЫ
}

Статья посвящена разработке теоретических положений по фрормированию логистической структуры товарного рынка и их конкретизации путем эмпирических исследований. Предложено авторское определение категории «логистическая цепь товарного рынка», обоснована его воспроизводственная природа и цель - обеспечение расширенного воспроизводства ресурсов в звеньях. В ходе исследования логистической структуры рынка доказано важную роль связей и взаимодействий между субъектами звеньев в формировании структуры эффективной логистической цепи, выделено семь типов связей, а именно: связи взаимодействия, образования, трансформации, строения, функционирования, развития и управления. Акцентировано внимание на связи взаимодействия, сделан вывод, что становление и развитие эффективных форм взаимодействия участников потокового процесса является необходимым условием достижения главной цели рыночной цепи.

Обоснована классификация логистических цепей товарных рынков, предложен новый классифрикационный признак - воспроизводственная способность рыночных цепей, которая позволяет осуществить их спецификацию по объемам создаваемой добавленной стоимости. Исследован процесс создания логистической составляющей добавленной стоимости в звеньях рыночной цепи, предложена классификация логистических операций. Впервые на основе воспроизводственного подхода установлена закономерность многофункциональной сущности логистической операции, которая заключается в сохранении, наращивании и преобразовании потребительской стоимости товара в процессе его движения по звеньям логистической цепи товарного рынка от первичного источника сырья до конечного потребителя готовой продукции и переработки отходов, что сопровождается ростом рыночной добавленной стоимости. Определены направления изменения потребительской и добавленной стоимости в рыночной цепи.

На примере украинского рынка зерна и продуктов его переработки определены специфика строения логистической цепи, прямые и обратные связи между ее звеньями. Установлено, что логистическая цепь зернового рынка является комбинированного типа, структуру которой фоормируют семь базовых звеньев, из них два - (переребатка зерна и утилизации отходов) малоэффективны, с незначительными объемами товаропотоков. Во временном измерении (1995-2017 гг.) показано трансформационное влияние растущих экспортных товаропотоков зерна на воспроизводственную способность рыночного цепи. Идентифицированы ее неэффективные звенья и связи, которые являются потенциальными объектами государственного селективного регулирования. Научная новизна проведенного исследования состоит в развитии теоретических основ рыночной логистики, как нового направления логистики, что формирует научную основу для разработки государственной логистической политики в рыночном измерении.

Ключевые слова: логистическая цепь товарного рынка, структура, связи, звено, логистическая операция, добавленная и потребительская стоимость, материальный поток, рынок зерна и продуктов его переработки.

\author{
Nikishyna 0. \\ Doctor of Economics, Senior Researcher \\ Head of Department of Market Mechanisms and Structures \\ Institute of Market Problems and Economic \& Ecological Research \\ of National Academy of Sciences of Ukraine \\ Frantsuzskiy boulevard, 29, Odesa, Ukraine, 65044 \\ E-mail: ksenkych@gmail.com \\ ORCID ID: 0000-0002-7172-3551
}

\section{LOGISTIC STRUCTURE OF THE COMMODITY MARKET: THEORETICAL POSITIONS AND APPLIED ASPECTS}

The article is devoted to the development of theoretical positions regarding the formation of the logistic structure of the commodity market and their concretization through empirical research. The author's definition of the category «logistic chain of the commodity market» has been proposed, its reproductive nature and pur- 
pose have been substantiated that is provision of expanded reproduction of the resources in links. During the study of the logistic structure of the market, the important role of the links and interactions between the actors of the links in the formation of the structure of the efficient logistic chain has been proved, and seven types of relationships have been identified, namely, the relationships of interaction, formation, transformation, structure, functioning, development and management. The emphasis has been placed on the relationships of interaction, it has been concluded that the formation and development of effective forms of interaction of participants in the streaming process is a prerequisite for achieving the main goal of the market chain.

The classification of logistic chains of commodity markets has been substantiated, a new classification sign has been proposed - reproductive ability of market chains, which allows them to fulfill their specification in terms of the created added value. The process of creation of the logistic component of added value in the market chain links has been investigated, the classification of logistic operations has been proposed. For the first time on the basis of the reproductive approach the regularity of the multifunctional essence of the logistic operation has been established, which consists in preserving, increasing and converting of the consumer value of the goods in the course of its movement for by the links of the logistic chain of the commodity market from the primary source of raw material to the final consumer of finished products and waste processing, which is accompanied by the growth of market added value. The directions of changes in consumer and added value in the market chain have been determined.

On the example of the Ukrainian market of grain and products of its processing, the specifics of the structure of the logistic chain, direct and back bonds between its links have been determined. It was established that the logistic chain of the grain market is of a combined type, the structure of which is formed by seven basic units, two of them - (grain processing and waste recycling) are ineffective, with small volumes of commodity flows. The temporal dimension (1995-2017) shows the transformational impact of growing export commodity flows of grain on the reproductive capacity of the market chain. Its ineffective links and bonds, which are potential objects of the state selective regulation, have been identified. The scientific novelty of the carried out research consists in development the theoretical foundations of market logistics as a new direction of logistics, which forms the scientific basis for the development of state logistics policy in the market dimension.

Key words: logistic chain of commodity market, structurebonds, link, logistic operation, added and consumer cost, material flow, grain market and products of its processing.

\section{References}

1. Smyrnov, I. H. (2009). Svitovyi rynok lohistychnykh posluh: Heohrafichni osoblyvosti. Isnyk Kyivskoho Universytetu, (46), 60-65.

2. Velychko, O. P. (2012). Sutnist lohistychnoho lantsiuha ta yoho kontrol suchasnymy ahrokholdynhamy. Visnyk Sotsialno-ekonomichnykh Doslidzhen, (3 (46)), ch. 2, 27-33.

3. Hirna, O. B., Hlynskyi, N. Yu., \& Kobyliukh, O. Ya. (2012). Formuvannia dodanoi vartosti dlia kliienta v lantsiuhu postavok. Lohistyka: Teoriia Ta Praktyka, (1 (2)), 39-46. politekhnika».

4. Krykavskyi, Ye. V., \& Chornopyska, N. V. (2009). Lohistychni systemy. Lviv: Vyd-vo Nats. un-tu «Lvivska

5. Ponomarova, Yu. V. (2005). Lohistyka (2nd ed.). Kyiv: Tsentr navchalnoi literatury.

6. Chukhrai, N. I., \& Hirna, O. B. (2007). Formuvannia lantsiuha postavok: Pytannia teorii ta praktyky. Lviv: «Intelekt-Zakhid». Ukrainy.

7. Burkynskyi, B. V., \& Lysiuk, V. M. (Eds.). (2018). Lohistyka tovarnoho rynku. Odesa: IPREED NAN

8. Tarakanov, M. L., \& Makovieiev, A. P. (2015). Lohistychnyi faktor formuvannia dodanoi vartosti v systemi tovarnykh rynkiv. Ekonomika: Realii Chasu, (2 (18)), 28-34.

9. Winkels, Heinz-Michael. (2000, January). Die logistische Kette. Retrieved April 05, 2019, from http://www.fhdo-winkels.de/Logistikmanagement/

10. Reznikova, N. V., \& Ivashchenko, O. A. (2015). Perspektyvy uchasti Ukrainy v hlobalnykh lantsiuhakh stvorennia vartosti yak zasib pidvyshchennia konkurentospromozhnosti v umovakh transnatsionalizatsii vyrobnychykh vidnosyn. Investytsii: Praktyka Ta Dosvid, (16), 22-26.

11. Ciesielski, M., Dlugosz, J., \& Fuks, K. (2011). Zarzadzanie lancuchami dostaw (M. Ciesielskii, Ed.). Warszava: PWE.

12. Ofitsiinyi sait Derzhavnoi sluzhby statystyky Ukrainy. Retrieved April 05, 2019, from http://www.ukrstat.gov.ua/

13. Prokopenko, O. M. (Ed.). (2018). Balansy ta spozhyvannia osnovnykh produktiv kharchuvannia naselenniam Ukrainy: Statystychnyi zbirnyk. Kyiv: Derzhavna sluzhba statystyky Ukrainy.

Received 9 April 2019

Approved 23 April 2019

Цитування згідно ДСТУ 8302:2015

Available in Internet 5.07.2019

Нікішина О.В. Логістична структура товарного ринку: теоретичні положення та прикладні аспекти // Економіка харчової промисловості. 2019. Т.11, вип. 2. С. 20-30. doi: 10.15673/fie.v11i2.1391

Cite as APA style citation

Nikishyna O. (2019). Logistic structure of the commodity market: theoretical positions and applied aspects. Food Industry Economics, 11(2), 20-30. doi: 10.15673/fie.v11i2.1391 